\title{
Necessity of a fintech global regulation
}

\section{Necesidad de una regulación mundial de Fintech}

DOI: https://doi.org/10.17981/juridcuc.17.1.2021.03

Fecha de Recepción: 2020/04/15 Fecha de Aceptación: 2020/09/18

\author{
Marlon Iván Maldonado Narváez 우 \\ Universidad Santo Tomás. Tunja (Colombia) \\ marlon.maldonado.n@outlook.com
}

Para citar este artículo:

Maldonado, M. (2021). Necessity of a fintech global regulation. Jurídicas CUC, 17(1), 65-86. DOI: http://dx.doi.org/10.17981/juridcuc.17.1.2021.03

\begin{abstract}
This article analyzes the need for international regulation for Fintech businesses. First, a brief analysis is made of the importance of the topic and the risks of the lack of good regulation. Subsequently, different cases of regulation are analyzed at the level of the traditional financial sector, as well as of some States that are considered decisive for the Fintech business, including Colombia, which has shown a good development of such ventures at the regional level. To achieve the task that we set ourselves, the deductive method was used, starting from the generality of the available information, and subsequently to an analysis of specific cases. Regarding the case study, it was a comparative study to offer a broader view of what should be the best applicable regulation. After this analysis, it was concluded that currently no state model would serve as an international model law and that what is required is a dialogue between States and businessmen to be able to approach the issue from different perspectives, in such a way that ensure economic growth and protection of both the economy and consumers internationally.
\end{abstract}

Keywords: Fintech; international regulation; policy-makers; Regtech; financial system

\section{Resumen}

En este artículo se analiza la necesidad de una regulación internacional para los negocios Fintech. Primeramente, se hace un breve análisis de la importancia del tema y de los riesgos de la carencia de una buena regulación. Posteriormente se analizan distintos casos de regulación a nivel del sector financiero tradicional, así como de algunos Estados que se consideran determinantes para el negocio Fintech, incluyendo a Colombia que ha mostrado un buen desarrollo de dichos emprendimientos a nivel regional. Para lograr el cometido que nos propusimos, se usó el método deductivo, partiendo de la generalidad de la información disponible, y posteriormente a un análisis de casos concretos. En lo relativo al estudio de casos se trató de un estudio comparado para ofrecer una visión más amplia sobre cuál debe ser la mejor regulación aplicable. Tras este análisis se llegó a la conclusión de que en la actualidad ningún modelo estatal serviría como ley modelo internacional, y que lo que se requiere es de un diálogo entre Estados y empresarios para poder abordar el tema desde distintas ópticas, de tal manera que se garantice el crecimiento económico y la protección tanto de la economía y de los consumidores a nivel internacional.

Palabras clave: Fintech; regulación internacional; legisladores; Regtech; sistema financiero 


\section{INTRODUCTION}

Remembering to Joseph Schumpeter (1943) from time to time, some innovations change the way to do things. These changes normally suppose the destruction of some jobs -traditional system-, and the creation of a better way of life. Globalization and the internet became a lot of changes in the way of life of people around the world. Between these changes, is possible to mention the affection to the traditional financial system, in part because of the growth of innovations that function through digital platforms more efficiently.

Those innovations, in particular, are knowing as Fintech; a concept that is possible to define as the breakthrough in the financial sector, making use of technological advances by some entrepreneurs. There is a growing number of entrepreneurs trying to participate in this sector, and at the same time, there is a growing number of people that are opting for Fintech services instead of traditional banking systems. For instance, in Colombia, during the worst day of the Coronavirus Pandemic, the banking sector denied loan applications because of the lack of a credit record; as a result, too many people opt for Fintech services.

But the problem is that for now, countries don't have clear regulation for Fintech. In some cases, regulations can be restricted. In other cases, regulation is excessively permissive. Furthermore, some businesses are managing self-regulation through artificial intelligence systems known as Regtech. In sum, this scenario can be dangerous because of the unclear, and for the risk of a new economic crisis. the situation that is exacerbated because the internet doesn't know country boundaries. While it is true that some countries are requiring licenses of functioning, that limitation works for business, but what about consumers that can navigate for whatever webpage around the internet around the world? For this reason, it is important to think of a Fintech global regulation. This way will be a more balanced development of these innovations, and better protection around the world for consumers and the economy to avoid a global crisis. 
However, what would be the better choice of regulation. The regulation of international financial systems doesn't appear like a good option. For instance, Basel Rules (Basel Committee on Banking Supervision, BCBS, 2017), are just thought for some great institutions, and some Fintech businesses are small size companies. On the other hand, countries' regulations are normally affected by pressures of banking businessmen as in the USA and Colombia. In other cases, as in China, there is a lack regulation that favors Fintech, creating risks on the balance of the economy; and in cases, as in the European Union (EU), it looks like regulations are designed more closely to the interest of some countries.

Considering all that situation, and by the use of the inductive method, and a comparative analysis of the information we can conclude that in this case there is a need for a multilateral dialogue. But not between policy-makers, but entrepreneurs and experts of the Fintech sector to achieve a wider vision of this process, and to protect consumers by achieving a good regulation to improve growing and being responsible to avoid a new international economic crisis.

\section{A general view}

Today, there are a lot of new ideas looking for an opportunity to obtain success. Entrepreneurs, now more than ever, with projects and inventions, are expecting just for the economic impulse needed to move their business. But, the difference today, is that thanks to the internet, those projects have a different choice to the traditional financial system, expanding financial access for entrepreneurs and consumers "at the bottom of the pyramid" (Di Castri, Grasser \& Kulenkampff, 2018, p. 7).

Financialization is a phenomenon that made people dependent on the financial system, especially the industrial sector out of the stock markets, that needed the approval of banks to get resources for new projects around research and development. Furthermore, was the crisis on the financial system the cause of the loss of faith in the banking sector (Maldonado, 2018). Besides the changes in the traditional way than the money works, because of the crypto- 
currencies (Vives, 2019). This scenario served to the emergence of new non-bank players in this game, who use technologies and the internet gained a great space in the field of financial business, that for years had been dominated for traditional financial institutions around the world.

Fintech, as its better known this process or this business, became an important part of world finance. Fintech business has been around for around 15 to 20 years, but it was since 2015 that it starts to grow as we know today (Deloitte, 2017). And there are more and more businesses and people taking part in this, as funders and as clients. Besides, all this process has internet as the principal platform around the world, that means than a regulation thought only in State borders is going to be pointless. Is undeniable that Fintech can create not only potential benefits but a lot of risks whether there isn't an international regulation about it; so this rises poses a real challenge for current financial regulation (Magnuson, 2018) and the need for a strong and smart actions.

An aspect that must be agreed that it is not a north-south movement. It is a technological movement, for equal in all directions, through the fintech that is growing at a speed almost impossible to stop for the States around the world. And that puts the structure of traditional economic models at risk, including the international financial system. The evidence shows that Americas as a region is in the top of the race, but when we see the data in detail, is possible to see that a city like Bogotá (Colombia) stands above cities like Washington and Houston in the USA, and a city like Vilnius in Lithuania stands above cities like Madrid, Frankfurt or Zurich (Findexable, 2019).

\section{What to regulate}

There is a need for international regulation of this to avoid the risk of a new global financial crisis considering the growing number of Fintech business. Besides, because there is a need to protect the consumers, considering that hackers and cyber criminals constantly are looking for new technologies to target and thieve (Foster, 2018). 
On the other hand, we have to consider the case of the bankruptcies of these companies (Delloite, 2017), the affectation of the consumer's rights, and in general the effect of this scenario in the international economy.

The fact is that in many countries, it is not yet clear how Fintech should operate (Arner, Barberis \& Bucley, 2017b), which means at the same time a gap in the regulation. Even, voices are claiming for less human intervention in all the processes, to reduce the possibility of human errors (Colaert, 2018). This is against the protectionist position of some states, that defends hard regulations to guarantee their economic equilibrium seems to be useless in the face of the onslaught of all new business models (Noya, 2016). Protectionism not only in terms of foreign investors but the great traditional sectors as bankers.

So, the first is that will need is permanent international cooperation, by understanding that digital technologies don't know any country's border. So, supervisory efforts and the construction of an architecture of data between authorities, is a primary necessity, for improved communication and control (Di Castri et al., 2018). Especially taking into account the global trust that people have in mobile platforms. A part of this is to ensure consistent compliance of financial institutions, more transparent to avoid situations as the 2008 crisis, even to avoid money laundering through digital services (De la Torre, 2018).

Besides, is needed a less conservative regulation, understanding that it should be designed not only for traditional domestic competitors, in many of which the Too big to fail, but the principle was also handled, and that is more framed in models of microfinance. As Magnuson (2018) mention, there are a lot of small actors who can present a systematic risk as well. But enough strong to keep permanent monitoring facing efficiency through the use of technology linking big data and compliance (Arner et al., 2017b). It's important to consider in the case of small companies that sometimes is just one person carrying a lot of functions, so this regulation should be proportional on the diversity size of different business (Colaert, 2018). 
So, it's important to think about the costs of regulation. After the 2008 financial crisis, it's well-known that the costs of regulation of the financial sector rocketed. And one attractive of Fintech is the lowers costs. That means than to be effective Fintech companies have to keep lower cost, and one way to achieve that is through a not expensive regulation, with flexibility and with the obligation of share accurate information and real-time data, as it's currently working (Johansson et al., 2019).

The last one is necessary to know that whatever regulation will need not only the knowledge of policymakers but the people in the Fintech sector. There is a trend known as RegTech, which means the self-regulation of the entities, by using programs and technologies to work better, without affecting the confidence of consumers (Klebeck, 2019). Without this support, any regulation surely will fail because of the lack of close management of this kind of technology and business.

\section{Financial Model: Basel Rules?}

This part can be started by saying that applying the same financial sector regulation to Fintech's businesses, or at least to new businesses not owned by a financial institution, would be the wrong decision. This position is based on the fact that there isn't and strong international regulation of the financial system. There is a trend to domestic regulation (Shapovalov, 2015) but not, to an international agreement. And, as has been affirmed, Fintech, is a business that works in digital platforms through the internet, that don't know any state border and are a free road, with the risk of colliding (Pricewaterhouse Coopers-PWC, 2019).

Thus, a model of minimum standards such as the one used in the Basel Rules for the banking sector, will not be sufficient, since it did not establish specific and clear mandatory rules that should be followed by the States and by international banks (Dowd, Hutchinson, Hinchliffe \& Ashby, 2011). As is known banking sector has great power in governmental decisions, and that is the reason why it's hard to achieve an international agreement with strong regulation 
because the close relationship between political and financial interests (Boehmer, Nash \& Netter, 2005); a position that is shared for Claessens \& Perotti (2007) who point out about financial regulation has inequality effects and that is a result of the power of banking sector. This is the opposite with Fintech, then as small players don't have too much power in power in political decision making

While Basel III includes several changes to amend the weakness of Basel I and II, it still not enough to be applied to Fintech. Besides Basel Rules are thought in a few competitors, meanwhile, there is a lot of new Fintech business beginning day in day out. Just one case of this was shown by Buchak, Matvos, Piskorski \& Seru (2018) who affirmed that in residential mortgage origination, shadow banks' market share doubled from 2007 to 2015. As I said, this means more and more competitors and the need of more than just some principles of acting.

However, Basel IV rules could be an option since this institution already has a basis for previous studies on the situation of international banking. That is, in order not to analyze real consequences through false premises, a true examination of the existing institutions at the global level is required, and their usefulness in the face of the challenge they face (Boyer \& Nyce, 2002).

Therefore, such regulation must be objective, and not protective of traditional financial institutions. In this case, can cite the example of the JOBS Act of 2012 of the United States, which has been strongly criticized for the limitation to one million dollars as a maximum amount of resources that a project can receive through crowdfunding. An aspect that somehow hinders the full realization of projects that seek to be funded, regardless of how strong they are.

Nor can it be a regulation that is excessively burdensome for digital enterprises and that eventually become an obstacle to its operation. It cannot be thought that, by collaborating with traditional banking, it will end an industry that has no brake and that could even lead to true illegality. Banks must understand that a correct regulation will also help them since there are many digital 
advances that they could also apply and thus reduce the costs of complying with the regulations that apply to it (Arner, Barberis \& Bucley, 2017a).

\section{Some models in analysis}

At this point, a good development for the construction of an international instrument is to identify state regulations. After identification, establish if your goal is to regulate all innovations through startups and Fintech. Finally, when determining whether such state regulations cover the most commonly used Fintech, establish what the common principles are applicable.

The importance of a rule-based on principles favors that its application is not restrictive for some models, but that it can be adapted to future digital companies that may arise, as well as to the different state models. But, the problem is that currently not all the countries have regulated Fintech. According to ASBA (Asociación de Supervisores Bancarios de las Américas, 2019), to 2018 less than 20 out of 38 jurisdictions in America had a regulation.

To consider the building of a Fintech international regulation, four cases of state regulation will be studied. In this study, models will be chosen from around the world, to see elements of different legal and political systems, and following the growth, it has had concerning the traditional financial institutions.

\section{Fintech Regulation in the USA ${ }^{1}$}

USA is the country with most regulation on the Fintech subject, because of the great number of regulators, starting by the fact of the federal government vs state regulation. But until the finishing of this research, there isn't any federal Act in the United States directly related to Fintech companies.

${ }^{1}$ In this section not going to mention the Dodd-Frank Act (2010), because this regulation was thought in the financial sector after the 2008 crisis, but not for Fintech business. 
For instance, can mention the restriction imposed by New York Department of Finance Services (DFS) to online lenders without a license in that State, considering this is as a threat to consumers and the regulations inside the State (Vullo, 2018); or the BitLicense that is a business license to negotiate with virtual currencies (New York State, NYS, 2014). Another case is the Virtual Currency Business Act, which according to the Uniform Law Commission (ULC, 2020) currently was introduced in the states of California, Oklahoma, and Hawaii, and establishes a regulatory framework for virtual-currency business, to protect consumers.

It can be said that this multiplicity of regulations can suppose a confusion and a weakness for the system and the introduction of new competitors in this market, and it is possible to stated that this is the result of the pressure of the banking sector. At the same time, this can mean major risks for consumers and the economy in general. As Magnuson (2018) mentions, Fintech companies are susceptible to more shocks than the banking sector because of this absence of a clear regulation.

Despite being at the top of the countries in the development Fintech's business, is possible to point that the USA shows some delay around good regulation. This lack of regulation becomes too in a barrier for foreign companies trying to compete in that market, so the only way to do it, is through partnerships with local companies (Nolasco, 2017).

However, the starting point for fintech business in the USA was the juncture created by the Jump-Start Our Business Act (2012), better known as the JOBs Act. Thanks to this regulation Crowdfunding business became popular, creating new investment opportunities (Morsy, 2014). But the problem with this regulation was then the ceiling of investment was short. Besides, that's not a punctual regulation to Fintech. As Cumming \& Schwienbacher (2018) said, there is too much money chasing deals, and this can mean a reduction in the average quality of such deals.

The most recent regulation is the Financial Services Innovation Act of 2019, which was thought to promote the innovation in this sector, and the mandate of the creation of the Financial Services 
Innovation Office, for all the different federal agencies that have any relation with Fintech $(\S 5)$. This to share information and monitor regulatory proposals related to financial innovations. It is possible to consider the Financial Services Innovation Act a step forward to find a federal regulation, in "the byzantine maze of financial regulations" (JD Alois, 2019, par. 4). But for now, it is needed is this act will work properly.

Between the around ten agencies that will have to operate in a more synchronic way, we can mention three of the most important:

- Securities and Exchange Commission (SEC). Currently this commission created FinHub, as a resource for information on the latest action advanced by this entity, and all the regulation imposed to Fintech companies (SEC, 2018).

- Office of the Comptrollers of the Currency (OCC). It looks for the responsible development of the innovation business inside the federal banking system (OCC, 2020).

- Commodity Futures Trading Commission (CFTC). This commission is related on the automated trading, in an algorithmic base, especially in the field of virtual currencies payments (CFTC, 2020).

\section{The efforts for a European Union Regulation}

This analysis is around the regulation of the Union, and not of the single countries. Different than in the USA, the EU is thinking of the most effective integration of the states to facilitate the cross-border flows of capital. Furthermore, the consumers' protection, financial system stability, and to keep competitiveness (European Parliament, 2017).

That was the starting point for the adoption of the Action Plan, which was thought to take advantage of the technology advance and to make safe the markets. According to the European Commission (EC, 2018), about this subject, the Vice-President responsible for Financial Stability of the European Unión, said that facilitate the access to capital to innovative companies will improve competitiveness. On the other hand, is equally important 
to keep a short distance between America and Asian countries (Jarne, 2018).

One program into the Action Plan is the creation of a Neutral Financial Technology Laboratory. This approach can be considered important in order to know which regulation is more convenient for Fintech, among the different national regulators (EC, 2018). This means, to achieve the knowledge to enact a good regulation for the financial sector and innovative Fintech.

Another important issue in the building of this Laboratory is the fact than it is a non-commercial initiative that will put to work together with vendors, innovators, and regulators. This implies a closing relation with all the categories and subcategories inside the Fintech concept. In the same way, working with technology providers will help to close to the RegTech, understood as self-regulation in the way of compliance that this business imposes to their participants. This means the use of new technologies to address regulatory requirements (Klebeck, 2019).

One result of this approach was about the requirements to obtain a license, an important topic in order to achieve a uniform operating conditions. Despite to be a general program in the Union, not all the members accept these practices (Chatzara, 2020); though, it was thanks to the good construction of the document, that before any imposition considered the different systems and the principles of proportionality and flexibility, to take the better decision (EC, 2018). Other programs oriented to better regulation of the Fintech in the European Union are the Blockchain Observatory and Forum (EUblockchain, 2020), to follow all the initiatives blockchain in Europe, sharing information and achieve transparency.

Though is premature to look for results of these programs, what is clear is that not all the countries in the EU move at the same speed. For instance, the United Kingdom (UK) shows a faster development than the rest of the states of the Union but is necessary to see the effects of the Brexit in that trend. Besides, Germany at the continental level is giving great steps. So, in this point, the conclusion is that besides the programs of the European Unión, is very important the support of the country government (Faia \& Paiella, 2019). 


\section{China's case: the other side of the same coin}

Innovation plays a central role in China, to achieve development through business startups and innovation by all the people (Central Committee of the Communist Party of China, 2015). This position is not new; it's visible since the 11th Five Years Plan China, adopted program for more inclusive financial services and wide adoption of technology. After that, in the 12th Five Years Plan, the country kept the same approach, by looking for the growing of e-transactions (Zhou, Arner \& Bucley, 2017).

Besides, the growth of Fintech in China, was in a good way thanks to the scarcity of technology of the financial system in that country. This lack gave to Fintech companies a great space for growing in a fast way (Chorzempa, 2018); and because of the restrictions for the entrance of international banks, in a good way due to a cultural distance, especially in a juridical sense (Gorjón, 2018). So, what can see, different from occidental countries, is that there was less pressure of the banking sector for a regulation or not regulation of the innovative business.

Another important aspect is that China's Fintech received great governmental support (Chorzempa, 2018; Gorjón, 2018). It can be considered, as in the other countries financial sector has great support of the governments because of his importance in the economy, is the same in China but with technologies companies as Baidu, Alibaba or Tencent. This is the way is possible to understand that in the 13th Five-Year Plan, for economic and social development, 2016-2020, was included in Part II, and even Part III, a wide range of measures to the growing of the sector (Central Committee of the Communist Party of China, 2015).

But, this difference, as Chorzempa (2018) said, is the dream of any hacker, and a nightmare for privacy; in a good way because of the great number of people connected to the internet, more than in any other country in the world (Gorjón, 2018), and for a permissive regulation. This situation had been that the government commits in a more balanced framework in order to improve the protection of all financial activities and consumers (Zhou et al., 2017). Even that was 
a requirement of the World Bank to improve a high-quality business environment, to adapt regulations in some Fintech areas (World Bank, 2019).

But this change has not been easy. To develop a good regulation, in the framework of the philosophy of the Communist Party, and in opposition to the technocrats who resists to a broad financial reform. This scenario has led to other issues less important than reform itself, in the way to a closed position with the western countries (Gruin \& Knaack, 2019). So what is truth, is that in China, as see, is the opposite side of the United States approach.

\section{Colombian regulation}

Colombia appears like a friendly country for innovation. Since 2017 the Financial Superintendence, the authority that watches and controls all the financial entities in the country, established a workgroup named InnovaSFC (SFC, 2020) focused on facilitating the innovation in this sector. The launch of a hub was a part of this project, and they have been working even with entities outside the control of the superintendence.

Besides, Decree 1357 (2018) enacted the regulation for crowdfunding. More recently, Decree 222 (2020), that opens the financial system for people before it did not have it, especially in remotes areas of the country. For Fintech business this means, according to the decree the possibility of operating with these people by lending money in small quantities.

Despite that, and the impulse of the sector, Colombia is late in building a good regulation of the innovative sector. For instance, Act 1955 (2019, Art. 166), "National Development Plan". That article establishes than it is possible to obtain a license to operate legally. This looks positive, but the negative side comes by the fact that the same article establishes the obligation of the government to regulate the terms of the license, and for now that is an unfinished task.

What see is that there is a strong financial sector formed by traditional banks, and with great influence in the government and policymakers. That means that all the steps to improve the growth 
of the Fintech innovation business in Colombia going to be short or slow in comparison with the speed of this sector.

\section{How to build it. Some recommendations}

The law building process is usually not easy. It is not easy too, achieve an agreement between states, especially when it comes to topics of interest such as the financial sector. However, it is a task to accomplish, reaching an agreement that does not push so hard that it leaves fintech development without possibilities, but that is not so lax that it can generate a new international financial crisis.

To build a global fintech regulation, the first thing is to understand the world more digitally, with a state jurisdiction that is less and less clear due to the absence of the physical element of financial systems (Lehmann, 2019). Taking the above as a starting point, a strong combination of technology and regulation is needed. This is an agreement that to successful need to reduce the political element. So, instead of continuing with excessive protectionism of traditional financial institutions, will be better to be understood as a paradigm shift with no return (Omarova, 2020).

This implies concertation with entrepreneurs, based on the understanding of the technological issue, but including economists and lawyers to achieve a point of equilibrium, in which innovation is made while analyzing the issues of financial sustainability and legal protection for consumers. In this way, excesses of optimism that can lead to a repetition of a crisis such as that of the Dot.com, or situations in which each company responds differently to the market, generating systemic risk would be avoided (Magnuson, 2018).

It is then a negotiation, alien to traditional structures, in which digital entrepreneurs will be the ones who should champion it, including some experimental exercises while reaching the point of efficiency (Omarova, 2020) and in which economists and jurists are in charge of guarantee that said creation is effectively a source of growth, observing the different norms that currently exist on financial regulation, they can be adapted and there is none, to guarantee a solid and lasting development, in the face of the public interest that is in middle of the process (Lehman, 2019). 
Finally, the result must become in a real international agreement between most states, because another way its effects would be not binding or a real answer to this important topic, generating paradises that let the growth of business without regulation affecting consumers around the world.

\section{Conclusions}

Currently, a change in the traditional financial system is being witnessed. This change looks so big, that we can suppose the finish so some financial institutions as today we met. This is because of the entrance of new competitors with great skills to offer more efficient services than the traditional banking sector.

A consequence of that changes, and the growth of the Fintech services, is the need for good regulation, thinking in develop a good environment for all the interested including customers. But for now, there isn't a regulatory body that we can consider as the correct answer for this necessity. Either for excessive restrictions or on the other side permissions or just because has been created without a wide insight of the interests at stake.

This situation is especially worrying because for consumers navigating the internet through a laptop or a mobile phone is possible to look for Fintech services in whatever country, far away from their state boundaries. So, it is not enough to think in good regulation, but in regulation at an international level, to protect consumers in the international economy at the same time.

So, a good international regulation will need the concert of the public and private sectors. And, between the private sectors, will have to achieve a trade the traditional financial organizations, and the Fintech entrepreneurs, understanding than together is only one way to guarantee economic growth. On the other hand, the public sector in an international sense will need an agreement between foreign policy-makers, understanding the fuzzy boundaries when it comes to the internet, and thinking in the protection of consumers, and finally to avoid another international financial crisis. 
True success of any regulation will come from understanding that it is a global need, which must come out of the classic positions of legal production, which means that fintech entrepreneurs, financiers and lawyers must enter into said dialogue to achieve a true balance point between the different interests at stake. Observing among the different existing legal systems which offer elements that may be useful for a global standard and which do not, so as to achieve the greatest consensus.

\section{REFERENCES}

Arner, D., Barberis, J. \& Bucley, R. (2017a). Fintech and Regtech in a nutshell, and the future in a sandbox. [Research Paper No. 2017/040]. Hong Kong: CFA Institute Research Foundation. https://doi.org/10.2139/ssrn.3088303

Arner, D., Barberis, J. \& Bucley, R. (2017b). RegTech: Building a better financial system. In: D. L. K. Chuen \& R. Deng (Ed.), Handbook of blockchain, digital finance, and inclusion, Volume 1 (pp. 359-373). Cambridge: Academic Press. https://doi.org/10.1016/B978-0-12-810441-5.00016-6

ASBA. (2019). Prácticas globales de regulación y supervisión de Fintech. [Regulación para la innovación responsable y competitiva del sector financiero]. Ciudad de México: ASBA y BID Lab. Recuperado de http://www.asbasupervision.com/es/ bibl/i-publicaciones-asba/i-1-grupos-de-trabajo/2206-practicas-globales-de-regulacion-y-supervision-de-fintech-1/file

BCBS. (december 7, 2017). Basel III: international regulatory framework for banks. [Online]. Available: https://www.bis. org/bcbs/basel3.htm

Boehmer, E., Nash, R. \& Netter, J. (2005). Bank privatization in developing and developed countries: Cross-sectional evidence on the impact of economic and political factors. Journal of Banking \& Finance, 29(8-9), 1981-2013. https://doi. org/10.1016/j.jbankfin.2005.03.004

Boyer, M. \& Nyce, Ch. (2002). Banks as Insurance Referral Agents? The convergence of financial services: evidence from the insurance industry. Cirano, (78). Available from https://cirano.qc.ca/files/publications/2002s-78.pdf 
Buchak, G., Matvos, G., Piskorski T. \& Seru, A. (2018). Fintech, regulatory arbitraje, and the rise of shadow Banks. Journal of Financial Economics, 130(3), 453-483. https://doi. org/10.1016/j.jfineco.2018.03.011

Central Committee of the Communit Party of China. (2015). The 13th Five-Year Plan for economic and social development of the Peoples Republic of China 2016-2020. [Online]. Available from https://en.ndrc.gov.cn/policyrelease_8233/201612/ P020191101482242850325.pdf

CFTC. (2020). Commodity Futures Trading Commision. [Online]. Available from https://www.cftc.gov/

Claessens, S. \& Perotti, E. (2007). Finance and inequality: Channels and evidence. Journal of Comparative Economics, 35(4), 748-773. https://doi.org/10.1016/j.jce.2007.07.002

Colaert, V. (2018). RegTech as a response to regulatory expansion in the financial sector. Proceedings of the 2017-12 European Forum for Securities Regulation. Vienna University of Economics and Business \& LMU Munich, Vienna, Austria. Available from https://papers.ssrn.com/sol3/papers. cfm?abstract_id=2677116

Cumming, D. \& Schwienbacher, A. (2018). Fintech Venture Capital. Corporate Governance: An international Review, 26(5), 374-389. https://doi.org/10.1111/corg.12256

Chorzempa, M. (2018, december 19). How China gor a head start in fintech, and why the west won't catch up. MIT Technology Review. [Online]. Available from https://www.technologyreview.com/2018/12/19/138354/how-china-got-a-headstart-in-fintech-and-why-the-west-wont-catch-up/

Chatzara, V. (2020). Fintech, Insurtech, and the Regulators. In: P. Marano \& K. Noussia (Ed.), Insurtech a Legal Regulatory View (pp. 3-25). New York: Springer International Publishing. https://doi.org/10.1007/978-3-030-27386-6_1

De La Torre, M. (2018). Utilización del sector financiero para el lavado de dinero: perspectiva desde la legislación ecuatoriana. Jurídicas CUC, 14(1), 145-166. https://doi.org/10.17981/ juridcuc.14.1.2018.07 
Deloitte. (2017). Fintech by the numbers. Incumbents, startups, investors adapt to maturing ecosystem. Deloite. [Online]. Available from https://www2.deloitte.com/ru/en/pages/financial-services/articles/fintech-by-the-numbers.html

Di Castri, S., Grasser, M. \& Kulenkampff, A. (2018). Financial Authorities in the era of data abundance. RegTech for regulators and SupTech solutions. BFA Global. [Online]. Availlable from https://papers.ssrn.com/sol3/papers. cfm?abstract_id=3249283

Dowd, K., Hutchinson, M., Hinchliffe, J. \& Ashby, S. (2011). Capital inadequacies: the dismal failure of the Basel regime of bank capital regulation. Policy Analysis, (681), 1-40. Available from http://ssrn.com/abstract=1961708

EU. EC. (2018, march 8). Fintech: Commission takes action for a more competitive and innovative financial market. [Press Release]. Available from https://ec.europa.eu/commission/ presscorner/detail/en/IP_18_1403

EU. EC. (2018). Fintech Action Plan: For a more competitive and innovative European financial sector. [Document 52018DC0109]. Available from https://eur-lex.europa.eu/ legal-content/EN/TXT/?uri=CELEX:52018DC0109

EU. European Parliament. (2017). On FinTech: The influence of technology on the future of the financial sector. [2016/2243 (INI)]. Available from https://www.europarl.europa.eu/ doceo/document/A-8-2017-0176_EN.html

EU. ULC. (2020). Virtual Currency Business Act, Regulation of. [Online]. Available from https://www.uniformlaws.org/ committees/community-home?CommunityKey=e104aaa8c10f-45a7-a34a-0423c2106778

EUBlockchain. (2020). Eu Blockchain Obseervatory \& Forum. [Online]. Available from https://www.eublockchainforum.eu/

Faia, E. \& Paiella, M. (2019). The role of Fintech for the Capital Markets Union. In: F. Allen, E. Faia, M.l Haliassos \& K. Langenbucher, (Ed.). Capital Markets Union and Beyond. Cambridge: The MIT Press. https://doi.org/10.7551/mitpress/11080.003.0014 
Findexable. (2019). The global fintech index 2020. Findexable Limited. [Online]. Available at: https://findexable.com/wp-content/uploads/2019/12/Findexable_Global-Fintech-Rankings-2020exSFA.pdf

Foster, J. (2018, december 4). 21 Teffifying cybercrime statistics. Data Connectors. [Online]. Available: https://www.dataconnectors.com/technews/21-terrifying-cyber-crime-statistics/

Gorjón, S. (2018). The growth of the Fintech industry in China: a singular case. Economic Bulletin, 4. Available from https:// https://www.bde.es/f/webbde/SES/Secciones/Publicaciones/InformesBoletinesRevistas/ArticulosAnaliticos/2018/ T4/descargar/Files/beaa1804-art29e.pdf

Gruin, J. \& Knaack, P. (2019). Not just another shadow bank: Chinese authoritarian capitalism in the "developmental" promise of digital innovation. New Political Economy, 25(3), 370-387. https://doi.org/10.1080/13563467.2018.156 2437

Jarne, P. (2018). La Unión Europea ante el reto de las Fintech. Algunas notas al Plan de Acción en materia de tecnología financiera. Revista de Estudios Europeos, (72), 118128. Available from http://www.ree-uva.es/index.php/ sumarios/2018/n-72-julio-diciembre-2018/155-la-unioneuropea-ante-el-reto-de-las-fintech-algunas-notas-al-plande-accion-en-materia-de-tecnologia-financiera

JD Alois. (2019, October 21). Financial Services Innovation Act seeks to mandate innovation offices in federal agencies that impact Fintech. Crowdfund Insider. [Online]. Available from https://www.crowdfundinsider.com/2019/10/153145financial-services-innovation-act-seeks-to-mandate-innovation-offices-in-federal-agencies-the-impact-fintech/

Johansson, E., Sutinen, K., Lassila, J., Lang, V., Martikainen, M. \& Lehner, O. (2019). Regtech. A necessary tool to keep up with compliance and regulatory changes? ACRN Oxford Journal of Finance and Risk Perspective, 8(Special Issue Digital Accounting), 71-82. Available: http://www.acrnjournals.eu/resources/SI08_2019f.pdf 
Klebeck, U. (2019). FinReg, FinTech, and RegTech -Quo Vadis, EU? In: J. Barberis, D. Arner \& R. P. Buckley (Ed.), The RegTech Book: the financial technology handbook for investors, entrepreneurs and visionaries in regulation (pp. 199-204). New Delhi: Millennial Ltd. https://doi. org/10.1002/9781119362197.ch38

Lehmann, M. (2019). Global Rules for a Global Market Place? - The regulation and supervision of Fintech Providers. [EBI Working Papers Series, 2019-no. 45]. Available from https://papers.ssrn.com/sol3/papers.cfm?abstract_ id $=3421963$

Magnuson, W. (2018). Regulating Fintech. Vanderbilt Law Review, 71(4), 1167-1226. Available from https:// scholarship.law.vanderbilt.edu/cgi/viewcontent. cgi? article $=1033 \&$ context $=$ vlr

Maldonado, M. (2018). El fenómeno de la financiarización y sus efectos sociales. Breve análisis del caso colombiano. In vestigium Ire, 12(1), 186-216, Available from http://revistas. ustatunja.edu.co/index.php/ivestigium/article/view/1697

Morsy, S. (2014). The JOBS Act and crowdfunding: How narrowing the secondary market handicaps fraud plaintiffs. Brooklyn Law Review, 39(3). 1373-1405. Available from https://brooklynworks.brooklaw.edu/cgi/viewcontent. cgi?article $=1059 \&$ context $=$ blr

Nolasco, M. (2017). El Mercado de Fintech en Estados Unidos. Noviembre 2017. [eM. Estudios de Mercado. Resumen Ejecutivo]. Madrid: ICEX. Available from https://www. icex.es/icex/es/navegacion-principal/todos-nuestrosservicios/informacion-de-mercados/paises/navegacionprincipal/el-mercado/estudios-informes/DOC2017773235. html?idPais=US

Noya, E. (2016). ¿Es el fintech el mayor desafío que afronta la banca? Revista Harvard Deusto, (254). Available from https:// www.harvard-deusto.com/es-el-fintech-el-mayor-desafioque-afronta-la-banca 
NYS. (november 7, 2014). Virtual Currency. [Online]. Available from https://www.dfs.ny.gov/apps_and_licensing/virtual_ currency_businesses/bitlicense_faqs

OCC. (2020). Office of the Comptoller of the Currency. [Online]. Available: https://www.occ.treas.gov/

Omarova, S. (2020). Dealing with disruption: emerging approaches to Fintech regulation. [Cornell Law School Research Paper, No. 20-17]. Available from https://papers.ssrn.com/ sol3/papers.cfm?abstract_id=3576609

PWC. (2019). Crossing the lines: How Fintech is propelling FS and TMT firms out of their lanes. [Global Fintech Report 2019]. Available from https://www.pwc.com/gx/en/industries/financial-services/assets/pwc-global-fintech-report-2019.pdf

Republic of Colombia. Presidency of the Republic. (February 14, 2020). By which Decree 2555 of 2010 is amended in relation to correspondents, electronic savings accounts, electronic deposits, low amount credit and other provisions. [Decree 222] Oficial Journal: 51.228. Available: http://svrpubindc. imprenta.gov.co/diario/index.xhtml

Republic of Colombia. Congress of the Republic. (July 31, 2018). By which Decree 2555 of 2010 is amended in relation to the activity of collaborative financing. [Decree 1357] OJ: 50.671. Available: http://svrpubindc.imprenta.gov.co/diario/ index.xhtml

Republic of Colombia. Congress of the Republic. (May. 25, 2019). National Development Plan 2018-2022. [Act 1955]. OJ: 50.964. Available: http://svrpubindc.imprenta.gov.co/diario/index.xhtml

Republic of Colombia. SFC. (2020). Innova SFC. [Online]. Available from https://www.superfinanciera.gov.co/jsp/10097165

Shapovalov, M. (2015). Derecho financiero internacional: Historia, estado actual y perspectivas de desarrollo. Dikaion, 24(1), 171-195. Disponible en https://dikaion.unisabana.edu.co/ index.php/dikaion/article/view/4324/4096

Schumpeter, J. (1943). Capitalism, Socialism and Democracy. London and New York: Routledge. 
USA. House of representatives. (2019). Financial Services Innovation Act of 2019. Res. 4767, 116th Cong. Reg. Available from https://www.congress.gov/bill/116th-congress/housebill $/ 4767 /$ text? $r=6 \& s=1$

USA. H. R. (2012). Small Company Capital Formation Act of 2011. Res. 1070, 112th Cong. Res. Available from https://www. congress.gov/bill/112th-congress/house-bill/1070

USA. H. R. (2010). Dodd-Frank Wall Street Reform and Consumer Protection Act. Res. 4173, 111th Cong. Reg. Available from https://www.congress.gov/bill/111th-congress/housebill/4173

USA. SEC. (october 1, 2018). FinHub. [Online]. Available from https://www.sec.gov/finhub

Vives, X. (2019). Digital Disruption in banking. Annual Review of Financial Economics, 11, 243-272. https://doi.org/10.1146/ annurev-financial-100719-120854

Vullo, M. (2018). New York State. Department of Financial Services. [Online Lending Report]. Available from https:// www.dfs.ny.gov/docs/reportpub/online_lending_survey_ rpt_07112018.pdf

World Bank. (2019). Country Partnership Framework for the People's Republic of China for the period FY 2020-2025. [Report No. 117875-CN]. Available from http://documents.worldbank. org/curated/en/902781575573489712/pdf/China-CountryPartnership-Framework-for-the-Period-FY2020-2025.pdf

Zhou, W., Arner, D. \& Bucley, R. (2017). Regulating Fintech in China: from permissive to balanced. In: D. Chuen \& R. Deng (Ed.), Handbook of Blockchain, Digital Finance, and Inclusion, Vol. 2 (pp. 45-64). London: Elsevier \& Academic Press. https://doi.org/10.1016/B978-0-12-812282-2.00003-6

Marlon Iván Maldonado Narváez, Lawyer, magister in business law, professor at Universidad Santo Tomás (Tunja, Colombia). https://orcid.org/0000-0002-2940-8638 